\title{
Tiptoeing away
}

\section{Susan Quilliam}

Writer, Broadcaster, Consultant and Trainer, Cambridge, UK

Correspondence to Ms Susan Quilliam; susan@susanquilliam.com; http://www.susanquilliam.com

Received 15 November 2015 Accepted 15 November 2015

\section{CrossMark}

To cite: Quilliam S. J Fam Plann Reprod Health Care 2016:42:71-73.

\section{BACKGROUND}

Twelve years. Forty-nine articles, including this one. And here we are at the end. The Consumer Correspondent column is taking its final bow.

It was in late summer 2003 that the Journal's former Editor-in-Chief, the late Anne Szarewski, first suggested I should write a column for the Journal which, in her words, "bridged the divide between patient and professional". I reacted as any competent lay writer would when asked to contribute to a highly esteemed medical academic journal - with total panic. Could I be medical enough? Could I be academic enough? Anne brushed aside my objections, telling me to leave all that to the other, clinically trained contributors. My job was to cast a deliberately unqualified eye on any issue that could help health professional readers understand how the patients themselves thought and, more importantly, felt.

\section{THE BEGINNING}

My first column ${ }^{1}$ was something of a baptism of fire. The Million Women Study had just been published and the ensuing mass dismay over the effect of hormone replacement therapy (HRT) on breast cancer susceptibility was making headlines. Anne tasked me to review the press coverage that was informing consumer opinion - and, by implication, consumer take-up of HRT - and to assess whether it was balanced or not.

The answer was 'not'. I perused a total of 34 national print press items - news, features, case studies and personal opinion pieces - ranging from five extended features in The Times to a 12-line bottom-of-the-page snippet in The Sun. Yes, the factual coverage was largely accurate; it was the emotional subtexts that worried me. A quarter of these pieces included no reassuring coverage to allay fears; those that did usually included such reassurance at the end of the item, overshadowed completely by the scaremongering headlines reading "Doubles the risk", "Devastating toll" or
"HRT claims two thousand victims". The result - as shown in subsequent years by the steep drop in HRT uptake - confirmed my initial conclusion whilst writing the article ${ }^{1}$ that the gap between health professional knowledge and patient understanding was wide. Well, at least I was now helping to close that gap.

\section{THE SUBJECTS}

In the years that followed, many Consumer Correspondent articles focused on the impact that media coverage of sexual and reproductive healthcare $(\mathrm{SRH})$ issues has on the consumer. Do teenage magazine advice columnists lead their readers astray? Did the British Department of Health's advertising campaign 'Chlamydia - worth talking about' do any good? The communicating of sexual information in other ways comprised a further strand. How high was the quality of sexual health education received by women in 18 European countries? Is the growing influence of the internet as an information source helpful to patients and clinicians?

I also explored the way in which medical problems such as premenstrual syndrome and endometriosis impact on sexual, in addition to reproductive, health, as well as how - vice versa support for patients' sexuality can enhance their quality of life even in the face of both acute and chronic medical conditions. I further reported back on how specific patient groups - such as pregnant women, people living with HIV and the elderly - experience our profession; the news I heard was not always good, but it needed to be heeded by Journal readers.

Over these 12 years, I have particularly explored how communication between consumer and clinician can go awry. I especially remember the column that I ended up calling the 'Cringe Report', which asked the crucial question of who tends to take the lead in the embarrassing and difficult health conversations which often characterise our consultations. ${ }^{2}$ The answer, if you're wondering, is that both 
patient and professional tend to hold back, feeling that they should respect the other's sensibilities; the result, while well-meaning, is often literal as well as metaphorical silence.

\section{THE FORMATS}

I found myself rotating - on average once every 12 months - four core approaches. I might do a simple overview of a consumer-relevant topic in our field - explaining it, then querying it, and challenging it. I might take a single media item - book, article, programme, broadcast - and use it to reflect just how our SRH field was being portrayed, and how the information and knowledge we hold was being passed on to consumers. Or I might conduct an in-depth interview with members of our profession to explore just how effectively - or not - they felt they created connection with consumers.

Perhaps my favourite format has been the straw poll. Never attempting to be statistically significant, the original aim of these was to introduce what are now known as 'patient voices'. I would e-mail all my contacts - mostly professional, sometimes personal and ask them to e-mail their contacts and solicit reallife consumer opinions. Such opinions were typically shouted long and loud, on everything from the human papillomavirus vaccine to experiences of abortion. Ironically, the largest such poll did not feature patients but sex therapists, and was done with the support of Relate, the College of Sexual and Relationship Therapists and the Institute of Psychosexual medicine. ${ }^{3}$ Its conclusion called for greater co-operation between medical and mental health professionals, which to be honest was exactly what I'd hoped they'd say.

\section{THE LOWS AND HIGHS}

The most stressful piece I have written? Undoubtedly the 2011 coverage of romantic fiction that brewed up a worldwide storm because I dared to suggest that such novels might influence readers' attitudes to intimate relationships. ${ }^{4}$ Despite the fact that I identified myself as one such reader, I actually received death threats. Though there was, I'm glad to say, a happy ending to this particular tale in that it helped to trigger a more academic article on the subject written by medical student Kundan Iqbal, which was joint winner of the Margaret Jackson Prize Essay in 2014. ${ }^{5}$

The most joyful pieces for me to write? Undoubtedly the ones that were inspired by passion, whether my own or that of Journal Editorial Board members who suggested topics for me to cover. How cervical cancer brings a patient, and her partner, face-to-face with her 'sexuality ... fertility ... mortality'. Whether 'hands on' sex therapy is a life-changing experience for a patient or something more akin to professionalised abuse. How female genital mutilation challenges all of us to examine our beliefs and our prejudices. And then, of course, there was the article critiquing 50 Shades of Grey...

What has unified the whole is a combination of two elements: Anne Szarewski's first formal brief to me to "bridge the divide between patient and professional" in tandem with her informal instruction to "stir it up ... challenge our readership ... don't be afraid of being contentious and emotive".

\section{THE PRESENT AND FUTURE}

And now? The wheel has, in many ways, come full circle. I write this final article on the publication day of the NICE Guideline on Menopause: Diagnosis and Management ${ }^{6}$ that refers back to the Million Women Study, responding to the criticisms of the study made in this Journal in $2012^{7}$ and reinterpreting the study's conclusions much more positively, thank heavens.

In many ways, of course, the wheel has spun a little backwards. My heart sinks when I see yet another tabloid headline bemoaning the inclusion of sex and relationships education in schools or when I read pessimistic misinterpretations of reproductive health statistics, and that's without mentioning the reorganisations, budget cuts and political oversights that have haunted our profession over the past 12 years.

Yet in so many ways the 'wheel' has rolled happily forward and brought us to a new place. We now live in a subtly different society from that of 2003; one that for all its difficulties comes much closer to achieving the goals I have been so strenuously advocating in this column. A society in which accurate and helpful health information and advice is much more freely and readily available to consumers. One in which psychological insight and support is at last beginning to be seen as essential to medical care rather than as a suspect adjunct. Where the connection between consumer and clinician is getting stronger and stronger; the voice of the patient ever more valued; consultation and co-operation ever more desired, ever more championed, ever more possible.

\section{THE END - AND NEW BEGINNINGS}

Why stop then? Here's why. I wondered, in the trepidation of first writing for this Journal, whether I would last 10 minutes, but my best fantasy goal was 10 years. After that, I figured, a change would be appropriate not only for me but also for the Journal. The completion of the decade, however, coincided with Anne Szarewski's untimely death, and that was no time to be leaving. Two years on, the loss less traumatic and the Journal's eyes turned to the future, it is time. [And I am by no means gone completely: you will still glimpse me writing occasional book reviews, event reports and organisation profiles for the Journal.]

I rest the Consumer Correspondent column not only with huge appreciation of the Journal, its editorial staff and above all you, its readers. I leave not only with fond memories of the challenges, the rewards 
and the sheer buzz of seeing my words on the page and my voice speaking out. Most importantly, I tiptoe away with huge optimism for the future of the bridge I was originally tasked to build. For me there is no better ending than that.

Competing interests None declared.

Provenance and peer review Commissioned; internally peer reviewed.

\section{REFERENCES}

1 Quilliam S. Hormone replacement therapy (HRT). J Fam Plann Reprod Health Care 2004;30:128-130.

2 Quilliam S. The Cringe Report': why patients don't dare ask questions, and what we can do about that. J Fam Plann Reprod Health Care 2011;37:110-112.
3 Quilliam S. Sex therapists make their voices heard. J Fam Plann Reprod Health Care 2012;38:196-198.

4 Quilliam S. "He seized her in his manly arms and bent his lips to hers...". The surprising impact that romantic novels have on our work. J Fam Plann Reprod Health Care 2011;37:179-181.

5 Iqbal K. The impact of romance novels on women's sexual and reproductive health. J Fam Plann Reprod Health Care 2014;40:300-302.

6 National Institute for Health and Care Excellence (NICE). Menopause: Diagnosis and Management (NICE Guideline 23). 2015. https://www.nice.org.uk/guidance/ng23 [accessed 13 November 2015].

7 Shapiro S, Farmer RDT, Stevenson JC, et al. Does hormone replacement therapy cause breast cancer? An application of causal principles to three studies. Part 4. The Million Women Study. J Fam Plann Reprod Health Care 2012;38:102-109. 